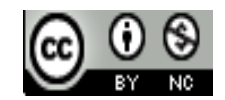

Journal of Education, Teaching, and Learning is licensed under a Creative Commons Attribution-Non Commercial 4.0 International License.

\title{
Aesthetic-Receptive and Critical-Creative in Appreciative Reading
}

\author{
Titin Setiartin \\ University Siliwangi, West Java, Indonesia \\ E-mail: setiar_tin@hotmail.com
}

\begin{abstract}
Reading is a process of aesthetically appreciative receptive to emphasize critical-creative reading activities. Metacognitively students understand, address any and explore the idea of the author in the text. Students responded, criticize, and evaluate the author's ideas in the text. At this stage, students can construct their post read text into other forms (new text). The aim of this strategy equips students to understand the meaning of the story, explore ideas, responding critically, and creatively pouring backstory idea. Reading strategies aesthetically-critical-creative receptive grabbed cognitive, effective, and psychomotor toward literacy critical reading and creative writing. Read appreciative included into the activities of reading comprehension. This activity involves the sensitivity and ability to process aesthetically-receptive reading and critical-creative. Readers imagination roam the author to obtain meaningful understanding and experience of reading. Some models of reading comprehension proposed experts covering the steps before reading, when reading, and after reading. At that stage to enable students after reading thinking abilities. Activities that can be done at this stage, for example, examine the back story, retell, make drawings, diagrams, or maps the concept of reading, as well as making a road map that describes the event. Other activities that can be done is to transform our student's text stories through reinforcement form illustrated stories into comic book form, for example (transliteration).
\end{abstract}

Keywords: reading appreciative, aesthetic process-critical-creative receptive

\section{INTRODUCTION}

Appreciative reading has the same characteristics and in line with the characteristics of information processing, which emphasizes the critical-creative reading activities. This process emphasizes activities to explore, understand, respond to, critical, evaluate, and appreciate, to appreciate and enjoy. In accordance with the opinion of Joyce \& Weil (2009: 252) subgroup sinektik opinion, based on the psychology of creativity Gordon (Joyce \& Weil, 2009: 252); Arends (2008: 16); and Satrock (2012: 351) states that metacognitive activities develop cognition as an active process, critical, and creative. Joyce \& Weil (2011: 7) states that its purpose is to help students gain information, ideas, skills, values, ways of thinking, the means to express themselves.

The realm of reading skills gained through observing activity, ask, try, reasoning, discuss, and create. This process is in line with the strategy of information processing sinektik. After reading activities provide opportunities for students to channel the desire of students created creations in some other form. I.e., try to construct form (text) of another.

\section{RESULTS AND DISCUSSION}

A. Discussion-Receptive Aesthetic Critical-Creative in Appreciative Reading

Segers (2000: 35-47) states that it is methodologically aesthetic reception trying to start a new direction in the study of literature because he holds that a literary text should be studied so that raises the reader reaction. Segers reception aesthetics mapped into three main sections, namely (1) the general concept of aesthetic reception; (2) the practical application of aesthetic reception; and (3) the position of the aesthetics of reception in the tradition of literary studies

In the literature, Aesthetics plays a very important role. Beauty says Plato (Teuw, 1988: 347) that are in the realm of ideas. Art as a thing of beauty for centuries the basis of the teachings of aesthetics. Jausz (Teuw, 1988: 348) found that the absolute beauty of human beings cannot be affordable. However, the beauty of the world can be approached through the thoughts and ideas with the ideal harmony. Western world aesthetic consequences on the art of devotion philosophy and ethics. Aesthetics give perspective to the study of literary semiotics. The development of absolute aesthetic objects that are in the artwork while the aesthetic experience that is in the audience (listeners, viewers, and readers). It is universally aesthetic theory into a literary approach. Therefore, the aesthetic approach of a place in the research literature. 
Aesthetics of a literary text into a media author draws readers into the world of creative imaginative. When the imagination of the reader trying to explore a text, the reader tried to approach the aesthetic values. The approach to a literary text is not limited to symbols semiotic approach. However, the reader seeks the overall content of the text. Aesthetic approach is a form of the reader to reach interpretation (understanding). "The literary work is an aesthetic object that is able to evoke the aesthetic experience of the reader. Appreciators (readers) to assess the literary works of literature by criteria aesthetic .... "(Wellek 1989: 321). Aesthetic experiences readers will be obtained from the interpretation in the process of reading receptive.

The reception is an interpretation of the audience (listeners, viewers, readers) to a work. As noted Endraswara (2002: 158) through the reception of literature, readers often imagine other when responding to literature. Psychiatric conditions often affect the reader also critical power. Furthermore, the reception is an approach used to understand literary works through the acceptance of readers, both the reader's contemporary writers, as well as the row on after the time of its creation (Teeuw, 2003: 269). Selden (1986: 112120) explains that the reception approach known several terms readings include: concretization (Fellix Vodicka), the horizon of hope (Hans Robert Jausz), implicit reader (Wolfgang, Izer), and the conventions of reading. "... various conventions or expectations are brought into play, connections are posited, and expectations Defeated or confirmed. To interpret a work is to tell a story of reading. "(Culler, 2000: 63) that the convention is expected as the work area between hope, failure or strengthen. The interpretation of a work of literature readers. Furthermore, "Thinking about readers and the way they make sense of literature has led to what has been called 'reader-response criticism', the which claims that the meaning of the text is the experience of the reader." (Culler, 2000: 63). Vodicka assumes that in the literature there is an empty space which can freely be filled in accordance with the social conditions of its readers, while Jausz considers that the readers' expectations horizon (the horizon of expectations) will enable the reception and processing inside the reader for the reading of literary texts.

Sekaitan with reception theory, Iser (1987: ix-xii; 54) suggests the concept of link text, the reader, and interactions that are the dialectical relationship between text, readers, and their interactions. Furthermore, Iser (1987: 20 and 54), calling it an aesthetic response because even though the centre of attention around the text, but direct perception and imagination of the reader in order to make adjustments and even distinguish the focus. The concept of dialectics aesthetic response, interactions can be observed through the sense implied reader, literary repertoire, and the literary strategies Implied reader is a model, rollers, and a standpoint that makes the reader as a real reader construct the meaning of the text. The repertoire is a set of social norms, historical, cultural and used for reading presented by text and is all familiar territory in the form of a reference text on the works there first. In the theory of literary reception, the reader tries to explore the author's imagination, with passion, excitement, and tension to the enjoyment. As Eagleton (1983: 82-83) states the Raeder simplycaught up in this exuberant dance of language, delighting in the texture of words themselves, the reader knows less the purposive pleasures of building a coherent system, building textual elements together masterfully to shore up a unitary self. Than the masochistic thrills of felling that self-shattered and dispersed through the tangled webs of the work itself

"Through this process, the reader has given the freedom to browse reading interpretation based schemata of the reader. Through this process, the reader can explore the author's imagination so that readers can concreated content of reading (story) in accordance with the wishes and creativity readers. Segers (2000: 35-47) says that methodologically aesthetic reception trying to start a new direction in the study of literature because of the view that a literary text should be studied (especially) in terms of reader reaction. Keywords of the concepts introduced Jauss is " wirkungsasthetik" response and effect ". According to him, readers rate, enjoy, interpret, and understand literature.

From a variety of expert opinion (Iser, Culler, Selden, and Segers) reception approach has the following outline: (1) is based on the relationship between literary texts and the reactions to his readers; (2) concreated meaning of the text is done through reader feedback, in accordance with the expectations horizon; (3) the imagination of the reader is made possible by its familiarity with the literature, ability to understand the circumstances of his time also earlier periods; and (4) through impressions, readers may file its response to a work read. Thus, the aesthetic reception is the reception and welcome readers to the literature. To that end, Teuw (1991: 12) argues, "The process of reading that gives meaning to a particular text, we choose, or are forced upon us (in teaching, for example) is a process that requires knowledge of the code system is quite complicated, complex, and diversity.

"the interpretation of the Latin word interpretation meaning 'interpretation' is generally an analysis that explains a text by one or various ideological approaches, the embodiment of the language, the historical truth, and so forth "the concept of literary appreciation the various forms of interpretation of the text is done, reader. Furthermore, from the interpretation or the interpretation of the term. Reception and interpretation, then the review, assessment, and the response is a concretization of the reading process by combining the aesthetic understanding, comprehension receptive, critical understanding, and creative understanding. In reading the whole aspect of it processed to achieve specific goals through the stages of (1) perception, (2) recognition, (3) comprehension, (4) interpretation, (5) evaluation, and (6) the creation or utilization.

Sumardjo (2000: 80) "Creativity is a condition, an attitude, or mental lived highly specialized nature and is almost impossible to formulate. Creativity is a mental activity that is very individual who is a manifestation of the freedom of her implicitly. "Ratna (2011: 15)" The creative process is an activity that is fully realized by the subject, the creative process is the accumulation of experiences of the past as seen through the present life today ". The creative process is 
dominated by the imagination, but it should be understood that according to the vision of the contemporary imagination is not merely an individual process but trans individual, imagination is also imagined by others ". Thus, a work (of art) literature is a critical-creative product of an author to the realities of life (phenomenon) is seen and felt by a person (the author).

The critical reading creative process is a process of reading done by someone who not only does the analysis but also synthetic; not only understand what is written but also implied. Based on the viewpoint of approach/pragmatic criticism, aesthetic process-critical-creative receptive and appreciative reading is doing excavation of the aspects of the extrinsic and intrinsic aspects of a literary work. It is, as stated Abrams (Pradopo, 1997: 34) "Critics pragmatic (pragmatic criticism) saw literature as a built to reach (get) certain effects on the audience (listener, reader), the either-the effect of aesthetic pleasure or education, or other securities.

"In this case, the development of reading skills appreciative through creative work (reading and creative writing). The concept of information processing (the information processing) belong to the cognitive learning theory put forward Slavin (2011: 217-218) that the work poses a memory when receiving the stimulus will bring the perception that involves the interpretation of thought, experience, knowledge, motivation, and interest, even the imagination, The information is understood and cared then transferred and stored the memory. Information stored subsequently processed and responded to, to draw conclusions in the context of verbal or visual.

The working process of the information processing work processes thoughts and feelings. Slavin (2011: 243-245) states that in verbal learning are among the learning visualization image in mind to improve memory. Many memory techniques which are based on the formation of a mental image to help remember the relationship. One method to increase the memory by using the depiction is to create a story to merge the information. Factors that create meaningful information is information which implies easier to learn.

In line with its opinion on the level of praxis, aesthetic receptive and critical-creative is a practical process of learning to read appreciatively. Several reasons, First, this mapping to be one approach to interpretation excavation students to find the meaning of folklore. Aspects of the aesthetic-receptive in the first reading a reference appreciative toward the ability to transform the text. Second, the aesthetic approach-reception have the following outline: a) is based on the relationship between literary texts and the reactions to his readers; b) concreated meaning of the text is done through reader feedback, in accordance with the expectations horizon; c) the imagination of the reader is made possible by its familiarity with the literature, ability to understand the circumstances of his time also earlier periods; and d) through impressions, readers may file its response to a work read.

In line with the opinion and Santrock Slavin (2012: 351), Joyce and Weil, argued that the information processing approach emphasizes children manipulate information, monitor, and get around. The essence of this approach is the memory and thought processes. Bertemali with information process approach, Allan Paivio (Santrock, 2012: 362) also argued that the memory is stored in two ways: as a verbal code or a code image or portrayal in mind. The more specific details code image, the better the memory of that information to encourage children to use their imaginations to remember verbal information. Based on the theory of creativity compose standpoint, this model is oriented to read literary theory and the theory of learning to read appreciative student-oriented role. read appreciative stages through the process of aestheticreceptive and critical-creative depicted in the following scheme.

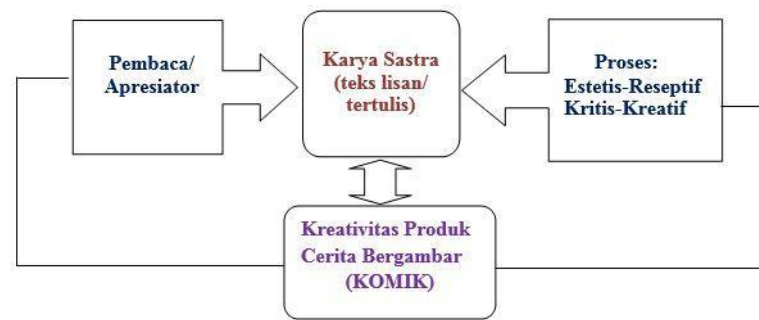

Fig. 1 Schematic Process-Receptive Aesthetic-Creative Critical

Process reading appreciative work consists of six phases Phase 1 Introduction to the Work. Information about the stories that will be transformed and text transformation work steps. Phase 2. read appreciative (appreciate works of literature), either fragmentary, a summary of the story, or simplification of the story. to determine the intrinsic elements of characters/characterization, background story, plot, theme, and mandate. Phase 3. discuss the intrinsic elements (characters/characterization, setting, plot, theme and mandate, as well as moral values, social, education). Furthermore, students share the task of working on worksheets and planning (step) to transform text of the story. Creative transformation change the literary work into the form of pictures or visual in accordance with the following steps: (1) planning (in order of the table), (2) develop scenarios, the guide features an image (characters, setting the scene, and the bubble), (3) me-lay out images, narration, and a speech bubble. Phase 4. in groups each made comment on pictures of other groups. With the guidance of teachers practice the students to discuss the features corresponding image with the characters in the story. Phase 5. Revisions and editing images based on input from other groups and teachers. Phase 6. The last phase is the publication of the results. Figure expected to be completed properly. In accordance with the creative process, students are given the freedom to imagine. Features that are provided may be changed or adjusted with interests of students.

\section{CONCLUSION}

From an aesthetic activity-receptive created critical-creative learning that encourages students to devote ideas and imagination critically and creatively. Students gain experience to appreciate and literary expression. Learning to read is an 
act appreciative to develop their skills toward an expected condition. Development and application of this learning model are based on the assessment of the appropriateness of instructional design criteria drafting, the order of the content, and composition lessons.

Learning to read appreciative strategy (process) aesthetically critical-creative-receptive consists of 6 phases. The initial activity of learning is preliminary and activities toward implementing the model. Terdidi learning core activities on 3 main phases (phase 1 to phase 3 ). The process of the activities in groups of students share the task of working on worksheets and planning (step) to transform text of the story: (a) planning (in order of the table), (b) Develop Scenarios, (c) Me-layout images, narration, and a speech bubble. With the guide features, creative students compose scenes picture images in accordance with the storyline. End activities, teachers, and students reflect on learning. Furthermore, students carry out the final text (post-test).

Correspondence between the steps taken by the teachers and students with learning procedures based on the suitability of an evaluation tool to measure: (1) the ability to read an appreciative student as an aesthetic activity-receptive and critical-creative; (2) the ability to transform text of folklore through the reinforcement form illustrated stories, as the activity of the product.

\section{REFERENCES}

Arends, Richard I. (2008). Learning to Teach. Learning to Teach. Book One and Book Two Translation, Yogyakarta: Student Library.

Culler, Jonatahan. (2000). Literary Theory A Verry Short Introduction. New York: Oxford University Press Inc. by

Eagleton, Terry. (2008). Literary Theory: An Introduction. (Comprehensive Introduction to Literary Theory) (New Edition). Literal translation Widyawati and Evi Setyarini. Yogyakarta and Bandung: Printing Jalasutra.

Iser, Wolfgang. (1987). The Act of Reading. Baltimore and London: The Johns Hopkins University Press.

Ratna, Nyoman Kutha. (2011). Role of Literature Anthropology Cultural Elements. Yogyakarta: Student Library.

Riffaterre, M. (1978). The Semiotics of Poetry. 'Creation of Text' Translated By Suminto A. Sayuti. London: Routledge \& Kegan Paul.

Santrock, John W. Psychology of Education. Educational Psychology. Buku1. Jakarta: Salemba Humanika.

Segers, Rien T. Evaluation of Literary Text. (2000). Translated by A. Suminto Sayuti. Yogyakarta: AdiCinta.

Slavin, Robert E. (2011). Psychology Education Theory and Practice. Volume 1 and Jilis 2. Translation. Jakarta: PT index.

Teeuw. A. (1988). Literature and Literary Studies: Introduction to the Theory of Literature. Jakarta: Pustaka Jaya.

Wellek, R. and Warren, A. (1956). Theory of Literature. New York: Harcout, Barance and Company. 